\title{
Leaf Wax Extracts of Four Deciduous Azalea Genotypes Affect Azalea Lace Bug (Stephanitis pyrioides Scott) Survival Rates and Behavior
}

\author{
Matthew Chappell and Carol Robacker ${ }^{1}$ \\ Department of Horticulture, University of Georgia, CAES Griffin Campus, 1109 Experiment Street, \\ Griffin, GA 30223
}

\begin{abstract}
AdDitional Index words. Rhododendron, deciduous azalea, epicuticular wax, insect resistance, chloroform wax extraction
Abstract. Azaleas (Ericales: Ericaceae: Rhododendron L.) are a staple plant in many landscapes of the United States and are largely resistant to predation by insects, with the exception of azalea lace bug [ALB (Heteroptera: Tingidae: Stephanitis pyrioides)]. Within deciduous azalea (Rhododendron: section Pentanthera G. Don) varying levels of resistance to ALB are observed with a continuous distribution from susceptible to highly resistant. In this study, epicuticular leaf wax from two ALB-resistant [R. canescens Michaux and $R$. periclymenoides (Michaux) Shinners] and two ALBsusceptible ('Buttercup' and 'My Mary') deciduous azalea genotypes was extracted and re-applied to fresh azalea foliage. Leaf wax extracted from ALB-resistant genotypes and applied to ALB-susceptible genotypes conferred a high level of resistance to both ALB feeding and oviposition in the treated ALB-susceptible genotypes. Conversely, leaf wax extracted from ALB-susceptible genotypes and applied to ALB-resistant genotypes conferred susceptibility to the treated ALB-resistant genotypes. However, the effect was much less substantial than the effect of resistant wax extracts on susceptible genotypes and confined to ALB oviposition. When applied to the same genotype from which the extract was collected, leaf wax extract from ALB-susceptible genotypes had no effect on susceptibility, whereas resistant wax extract had a moderate effect on ALB oviposition rate. The results indicate that leaf wax serves as a primary mechanism of resistance of deciduous azalea to ALB.
\end{abstract}

Since its introduction from Japan in 1915, azalea lace bug (ALB) has become a significant pest on azalea throughout North America (Drake and Ruhoff, 1965; Weiss, 1916). ALB damage occurs from late spring until leaf drop, as up to four generations can occur in a single growing season (Neal and Douglass, 1988). Adult and nymphal ALB feed on the abaxial leaf surface by inserting stylets into stomata (Ishihara and Kawai, 1981). Chloroplasts and other cell contents are removed from the mesophyll layer, resulting in speckling on foliage of susceptible species and cultivars. Additionally, cast skins of nymphs and brown to black frass deposition on the leaf further discolor foliage (Braman and Pendley, 1992; Buntin et al., 1996; Ishihara and Kawai, 1981; Mead, 1967).

Bioassays performed by Braman and Pendley (1992) found the deciduous $R$. canescens and $R$. prunifolium (Small) Millais to be resistant, whereas the evergreen cultivar Delaware Valley White [a selection of $R$. indica (L.) Sweet] was susceptible. Further work by Wang et al. (1998) evaluated four cultivars and 11 deciduous species selections and found $R$. periclymenoides, $R$. canescens, and $R$. prunifolium to be highly resistant and $R$. serrulatum (Small) Ahles and R. viscosum (L.) Torrey to show moderate resistance to ALB. Moderately susceptible to very susceptible species included $R$. arborescens (Purch) Torrey, $R$. austrinum (Small) Rehder, and R. oblongifolium (Small) Millais. Susceptible cultivars included 'Buttercup', a R. austrinum selection; 'My Mary', a complex hybrid of [R.atlanticum (Ashe) Rehd. $\mathrm{x} R$. periclymenoides $] \mathrm{x} R$. austrinum seletion; and 'Nacoochee', a $R$. atlanticum $\times R$. periclymenoides hybrid.

Received for publication 1 July 2005. Accepted for publication 16 Oct. 2005. We thank Drs. Kris Braman and Bodie Pennisi for review of the manuscript and constructive criticism. We also thank Allen Byous for maintenance of field plots and Sherrod Baden for her assistance in ALB collection and data collection. 1Corresponding author. E-mail address: croback@griffin.uga.edu
The principle function of the plant cuticle is to prevent excessive water loss (Hopkins, 1995). The epicuticular wax layer of the cuticle consists of long-chain aliphatic compounds derived from fatty acid chains. This wax layer is deposited on the leaf surface as amorphous intracuticular wax embedded in cutin polymers, as well as wax crystalloids. Epicuticular wax components include alkanes, primary and secondary alcohols, ketones, and wax esters (Eigenbrode and Espelie, 1995; Knust and Samuels, 2003). Epicuticular wax has been recognized as a deterrent to feeding and oviposition by herbivorous insects as well as an attractant of beneficial (often predatory) insects (Eigenbrode and Espelie, 1995). Specific examples of epiculticular wax-herbivore interactions have been identified and characterized in Allium cepa L. (Molenaar, 1984), Brassica rapa L. (Bodnaryk, 1992; Srinivasachar and Malik, 1972), Eucalyptus globulus Labill (Brennan and Weinbaum, 2001), Glycine max L. (Baker et al., 1985), Hordeum vulgare L. (Tsumuki et al., 1989), Sorghum bicolor (L.) Moench (Chapman et al., 1983; Nwanze et al., 1992; Weibel and Starks, 1986), and Triticum aestivum L. (Lowe et al., 1985).

In azalea, through the use of gas chromatography- mass spectrometry, specific lipid components of epicuticular wax have been implicated in ALB resistance and susceptibility (Balsdon et al., 1995; Wang et al., 1999). Research by Balsdon et al. (1995), analyzing lipid components of four susceptible evergreen cultivars and the resistant species $R$. canescens, identified three triterpenoid components that may have an effect on ALB behavior. However, data were not definitive as purported deterrent/stimulant compounds were found in similar concentrations in both $R$. canescens and the susceptible cultivars. Wang et al. (1999) identified lipid components correlated with ALB resistance and susceptibility in two deciduous resistant genotypes, four deciduous susceptible genotypes, and one evergreen susceptible azalea genotype. The lipid component present in the largest proportion among resistant genotypes was $n$-Henrtriacontane, whereas in susceptible genotypes $\alpha$ - and $\beta$-amyrin were in greatest concentrations. While 
these studies suggest an association of leaf-surface lipids with ALB response, studies to quantify the actual effects of lipids on ALB behavior have not been conducted. The research described in this paper investigates the quantitative effects of leaf-surface lipids from susceptible and resistant foliage on ALB survival, feeding, and oviposition.

\section{Materials and Methods}

Plant materials. Genotypes included in this study were selected based upon previous bioassays that screened azaleas for response to ALB (Braman and Pendley, 1992; Wang et al., 1998). The azalea genotypes included in this study were the resistant $R$. periclymenoides and $R$. canescens and the susceptible 'Buttercup' ( $R$. austrinum selection) and 'My Mary' (Beasley hybrid). Due to a lack of sufficient numbers of adult female ALB, the experiment was undertaken in two parts. $R$. periclymenoides and 'Buttercup' were paired and tested 30 Aug. 2004 followed 1 week later by $R$. canescens and 'My Mary'. All plant material used in this research was obtained in Aug. 2004 from mature field-grown plants grown under mixed deciduous tree species. The field plots were established in Nov. 1994 and maintained through drip irrigation and annual fertilization with Osmocote Pro Controlled Release Fertilizer Plus Minors (19N-2.2P-7.5K; Scotts-Sierra Horticultural Products Co., Marysville, Ohio). No pesticides were applied.

LABORATORY BIOASSAYS. Bioassays were conducted by extracting epicuticular leaf wax from two ALB-resistant and two ALBsusceptible deciduous azalea genotypes and re-applying to fresh azalea foliage of each of the four genotypes in a diallel design. Following leaf wax extraction and re-application, ALB were introduced to foliage in a closed and controlled environment and ALB survival, frass deposition, and oviposition were measured. To extract leaf wax, 40 azalea leaves per genotype were air-dried for $120 \mathrm{~h}$, then immersed in $100 \mathrm{~mL}$ of chloroform for $15 \mathrm{~s}$. Chloroform was evaporated and the remaining epicuticular wax re-suspended in a 50-mL 2 ethanol : 1 deionized water solution under mild heating $\left(32.2^{\circ} \mathrm{C}\right)$ and stirring. Upon cooling to room temperature $\left(20^{\circ} \mathrm{C}\right)$, the resulting solution was applied directly to the fresh foliage of a 4-5 cm cutting with two leaves. The leaf wax solution was applied by painting the solution on one side of the midrib, on both abaxial and adaxial surfaces. By applying solution to only one side of the midrib, the experiment served as a choice test, thereby allowing pairwise comparisons to be made between treated and untreated leaf surfaces. After the treatment was applied to both leaves of the cutting, the stem was inserted through a snap-on lid into a 32-mL plastic cup $(4 \mathrm{~cm}$ high $\times 4$ $\mathrm{cm}$ diameter) of water. Four female adult ALB were placed into a second $32-\mathrm{mL}$ cup that was modified by replacing the bottom of the cup with organdy screen to allow ventilation. This cup was inverted and placed over the cutting, and was sealed to the water cup with Parafilm M (Fisher Scientific, Hampton, N.H.). Mature, female azalea lace bugs were collected the day of the experiment from evergreen azaleas located in the Griffin, Ga., area.

EXPERIMENTAL DESIGN. Experimental design was a full diallel, including two controls: 1 ) solution-only (2 ethanol : 1 deionized water solution) heated and stirred, without wax extract) and 2) nontreated leaf. The study had four treatment groups (Table 1), each consisting of a donor of epicuticular wax extract, recipient of epicuticular wax extract, solution-only control, and nontreated control. Each treatment was applied to five cuttings, with two leaves per cutting; hence five replications were employed with two sub-samples per replication. Experimental conditions were controlled by placing all entries into a growth chamber at $24{ }^{\circ} \mathrm{C}$ and 12-h daylength for $120 \mathrm{~h}$.

Data Collection and STATistical anAlysis. Data were collected $96 \mathrm{~h}$ after ALB were introduced to azalea foliage. Numbers of live adults, frass spots (insect excrement), and eggs were recorded. Frass and egg data were recorded separately for treated and nontreated sides of each leaf, including solution-only and nontreated controls. Data were analyzed as a three-factor factorial in SAS using Proc GLM (SAS Institute, Cary, N.C.); the three factors were replications; donor of epicuticular leaf wax; and recipient of epicuticular wax. Mean values were compared using LSD analysis based upon the recipient of each leaf wax extract, including controls of nontreated foliage and solutiononly treatment. Additionally, pairwise comparisons (dependent group $t$ test) were performed between frass counts on treated and untreated sides of foliage as well as egg counts on treated and untreated sides of foliage. Data subsets were constructed based on: 1) susceptible genotypes used as leaf wax donor and resistant genotypes as leaf wax recipient, 2) resistant genotypes used as leaf wax donor and susceptible genotypes used as leaf wax recipient, 3 ) susceptible genotypes used as leaf wax donor and recipient (self), 4) resistant genotypes used as leaf wax donor and recipient (self), 5) solution-only control treatment on susceptible and resistant genotypes, respectively.

Additional studies to exClude treatment efFects. To investigate the possibility that residual chloroform was contaminating the wax extract solution and thus affecting results, leaf wax samples from $R$. periclymenoides, $R$. canescens, and 'Buttercup' were screened in a Tekmar purge-and-trap gas chromatography unit (Teledyne Tekmar, Mason, Ohio) for chloroform residue. Additionally, the application of wax solution to leaf surfaces may have clogged open stomata with wax particles, preventing ALB feeding. To determine whether stomata were obstructed, foliage of $R$. periclymenoides, $R$. canescens, and 'Buttercup' was treated with leaf wax extract from each of the three genotypes and examined under a LEO 982 field emission scanning electron microscope [FE-SEM (LEO Electron Microsopy, Thornwood, N.Y.)] with a Gatan Alto 2500 Cryostage and cryoprep chamber (Gatan UK, Oxford, U.K.). Three leaf sections measuring 100 $\mu \mathrm{m}^{2}$ per genotype, were photographed and all fully and partially open stomata scored as mechanically obstructed by accumulation of wax debris or unobstructed, with simple ratios calculated as a percentage of unclogged stomata per $100 \mu \mathrm{m}^{2}$.

\section{Results and Discussion}

Azalea lace bug survival. Variances from the two tests, performed 1 week apart, were homogeneous based on Bartlett's test for homogeneity of variance at $P>0.05$ (data not shown). Hence, data from the two independent experiments were combined and analyzed as a single data set. The first of three parameters assessed in this study, ALB survival, directly measures the deterrent effects of epicuticular leaf wax. Results indicate that epicuticular leaf wax from ALB-resistant genotypes contains a strong deterrent, as ALB survival was dramatically reduced when foliage of susceptible genotypes were treated with wax extract from resistant genotypes. When 'Buttercup' foliage was treated with $R$. periclymenoides wax extract, ALB survival was reduced from the 'Buttercup' nontreated and solution-only means of 2.9 and 3.0, respectively, to 0.6 (Table 1). This mean of 0.6 is comparable to the ALB survival on $R$. periclymenoides foliage 
treated with $R$. periclymenoides wax extract. Similarly, when 'My Mary' foliage was treated with $R$. canescens wax extract, ALB survival was reduced from the 'My Mary' nontreated and solution-only means of 3.0 and 2.9 , respectively, to 1.0 . This 1.0 ALB survival rate is comparable to that of $R$. canescens foliage treated with $R$. canescens wax extract.

Results point to an inverse effect as well, as leaf wax extracts from susceptible genotypes conferred susceptibility when applied to resistant genotypes. When 'Buttercup' wax extract was applied to $R$. periclymenoides foliage, ALB survival was increased from the $R$. periclymenoides nontreated and solution-only means of 1.0 and 1.4 , respectively, to 3.2 . This 3.2 value is comparable to that of 'Buttercup' foliage treated with 'Buttercup' wax extract $(\bar{x}=3.1)$. Similarly, when 'My Mary' wax extract was applied to $R$. canescens foliage, ALB survival was increased from the $R$. canescens nontreated and solution-only means of 0.8 and 0.9 , respectively, to 3.2 . This 3.2 value is comparable to that of 'My Mary' foliage treated with 'My Mary' wax extract $(\bar{x}=2.9)$. Treatment of leaf surfaces with wax from the same genotype had no statistically significant effect on the level of resistance or susceptibility compared to nontreated or solution-only controls. $R$. periclymenoides foliage treated with $R$. periclymenoides wax extract had a mean ALB survival of 0.6, with nontreated and solution-only means statistically similar at 1.0 and 1.4, respectively. 'Buttercup' foliage treated with 'Buttercup' wax extract had a mean ALB survival of 3.1, with nontreated and solution-only means statistically similar at 2.9 and 3.0, respectively. Both $R$. canescens and 'My Mary' treatment of leaf surfaces with wax from the same genotypes followed this pattern.
Azalea laCe bug fRASS Deposition. The number of frass spots is a direct assessment of ALB feeding. Frass deposition on foliage of susceptible genotypes treated with resistant wax extract were significantly reduced compared to susceptible controls, due to both mortality of ALB in these treatment combinations and a reduction in feeding of live ALB. Mean number of frass spots from 'Buttercup' leaf surfaces treated with $R$. periclymenoides wax extract was reduced from the solution-only mean of 66.5 to 5.9 (Table 1). Mean number of frass spots from 'My Mary' leaf surfaces treated with $R$. canescens wax extract was reduced from the 'My Mary' solution-only mean of 56.3 to 16.6. Photos of feeding damage and frass deposition on 'My Mary' foliage treated with $R$. canescens wax extract is shown in Fig. 1. Conversely, when wax extracts from susceptible genotypes were applied to resistant genotypes, treated leaf surfaces of resistant genotypes exhibited a susceptible response to ALB. Mean number of frass spots on R. periclymenoides leaf surfaces treated with 'Buttercup' wax extract was increased from the $R$. periclymenoides solutiononly mean of 19.2 to 46.6. Similarly, mean number of frass spots on $R$. canescens leaf surfaces treated with 'My Mary' wax extract was increased from the $R$. canescens solution-only mean of 8.8 to 44.6. This treatment effect is seen in the Fig. 1 photograph of a $R$. canescens leaf treated with 'My Mary' wax extract.

Treatment of leaf surfaces with wax extracted from the same genotype showed no significant effect on the level of resistance. Mean number of frass spots on $R$. canescens leaf surfaces treated with $R$. canescens wax extract was 11.8 , comparable to that of the solution-only mean 8.8. Similarly, mean number of frass spots on $R$. periclymenoides leaf surfaces treated with $R$. periclymenoides

Table 1. Numbers of surviving adult female azalea lace bugs, frass spots, and eggs on azalea foliage treated with epicuticular wax extract from resistant (Rhododendron periclymenoides, $R$. canescens) or susceptible ('Buttercup', 'My Mary') azalea foliage. Numbers are means of five replications and data are grouped based on the recipient of leaf wax. Mean separation is based upon least significant difference (LSD) at $P<$ 0.05. Means followed by the same letters for each parameter-leaf wax recipient combination are not statistically different.

\begin{tabular}{|c|c|c|c|c|c|c|c|c|c|c|}
\hline & \multicolumn{2}{|c|}{ Surviving lace bugs ${ }^{\mathrm{z}}$} & \multicolumn{2}{|c|}{ Frass treated surfaces ${ }^{\mathrm{y}}$} & \multicolumn{2}{|c|}{ Frass non-treated surfaces ${ }^{x}$} & \multicolumn{2}{|c|}{ Eggs treated surfaces ${ }^{\mathrm{w}}$} & \multicolumn{2}{|c|}{ Eggs nontreated surfaces $^{\mathrm{v}}$} \\
\hline \multicolumn{11}{|c|}{ 'Buttercup' leaves (susceptible) ${ }^{\mathrm{u}}$} \\
\hline $\begin{array}{l}\text { Wax } \\
\text { treatment } \\
P<\mathrm{F}\end{array}$ & $\begin{array}{l}\text { 'Buttercup' } \\
\text { Solution-only } \\
\text { Nontreated } \\
\text { R. periclymenoides }\end{array}$ & $\begin{array}{l}3.1^{\mathrm{s}} \mathrm{a}^{\mathrm{r}} \\
3.0 \mathrm{a} \\
2.9 \mathrm{a} \\
0.6 \mathrm{~b} \\
<0.0001\end{array}$ & $\begin{array}{l}\text { 'Buttercup' } \\
\text { Solution-only } \\
\text { R. periclymenoides }\end{array}$ & $\begin{array}{r}67.6 \mathrm{a} \\
66.5 \mathrm{a} \\
5.9 \mathrm{~b} \\
0.0054\end{array}$ & $\begin{array}{l}\text { Nontreated } \\
\text { 'Buttercup' } \\
\text { Solution-only } \\
R \text {. periclymenoides }\end{array}$ & $\begin{array}{r}112.9 \mathrm{a} \\
84.3 \mathrm{a} \\
68.7 \mathrm{a} \\
6.5 \mathrm{~b} \\
0.0055\end{array}$ & $\begin{array}{l}\text { 'Buttercup' } \\
\text { Solution-only } \\
R \text {. periclymenoides }\end{array}$ & $\begin{array}{r}14.8 \mathrm{a} \\
14.6 \mathrm{a} \\
0.9 \mathrm{~b} \\
\\
0.0027\end{array}$ & $\begin{array}{l}\text { Nontreated } \\
\text { 'Buttercup' } \\
\text { Solution-only } \\
\text { R. periclymenoides }\end{array}$ & $\begin{array}{l}25.9 \mathrm{a} \\
17.2 \mathrm{ab} \\
13.8 \mathrm{~b} \\
0.3 \mathrm{c} \\
0.0046\end{array}$ \\
\hline \multicolumn{11}{|c|}{ 'My Mary' leaves (susceptible) } \\
\hline $\begin{array}{l}\text { Wax } \\
\text { treatment } \\
P<\mathrm{F}\end{array}$ & $\begin{array}{l}\text { Non-treated } \\
\text { 'My Mary' } \\
\text { Solution-only } \\
\text { R. canescens }\end{array}$ & $\begin{array}{l}3.0 \mathrm{a} \\
2.9 \mathrm{a} \\
2.9 \mathrm{a} \\
1.0 \mathrm{~b} \\
0.0038\end{array}$ & $\begin{array}{l}\text { 'My Mary' } \\
\text { Solution-only } \\
R \text {. canescens }\end{array}$ & $\begin{array}{r}80.1 \mathrm{a} \\
56.3 \mathrm{~b} \\
16.6 \mathrm{c} \\
<0.0001\end{array}$ & $\begin{array}{l}\text { Nontreated } \\
\text { 'My Mary' } \\
\text { Solution-only } \\
\text { R. canescens }\end{array}$ & $\begin{array}{c}119.3 \mathrm{a} \\
93.3 \mathrm{~b} \\
56.6 \mathrm{c} \\
13.1 \mathrm{~d} \\
<0.0001\end{array}$ & $\begin{array}{l}\text { 'My Mary' } \\
\text { Solution-only } \\
\text { R. canescens }\end{array}$ & $\begin{array}{r}18.8 \mathrm{a} \\
13.3 \mathrm{~b} \\
1.5 \mathrm{c} \\
\\
0.0004\end{array}$ & $\begin{array}{l}\text { Nontreated } \\
\text { 'My Mary' } \\
\text { Solution-only } \\
\text { R. canescens }\end{array}$ & $\begin{array}{l}29.4 \mathrm{a} \\
18.7 \mathrm{~b} \\
12.7 \mathrm{~b} \\
0.3 \mathrm{c} \\
<0.0001\end{array}$ \\
\hline \multicolumn{11}{|c|}{ R. periclymenoides leaves (resistant) } \\
\hline $\begin{array}{l}\text { Wax } \\
\text { treatment } \\
P<\mathrm{F}\end{array}$ & $\begin{array}{l}\text { 'Buttercup' } \\
\text { Solution-only } \\
\text { Nontreated } \\
\text { R. periclymenoides }\end{array}$ & $\begin{array}{l}3.2 \mathrm{a} \\
1.4 \mathrm{~b} \\
1.0 \mathrm{~b} \\
0.6 \mathrm{~b} \\
0.0015\end{array}$ & $\begin{array}{l}\text { 'Buttercup' } \\
\text { Solution-only } \\
R \text {. periclymenoides }\end{array}$ & $\begin{array}{r}46.6 \mathrm{a} \\
19.2 \mathrm{~b} \\
2.9 \mathrm{~b} \\
\\
0.0033\end{array}$ & $\begin{array}{l}\text { 'Buttercup' } \\
\text { Nontreated } \\
\text { Solution-only } \\
\text { R. periclymenoides }\end{array}$ & $\begin{array}{l}82.6 \mathrm{a} \\
47.5 \mathrm{~b} \\
20.4 \mathrm{bc} \\
8.1 \mathrm{c} \\
0.0038\end{array}$ & $\begin{array}{l}\text { 'Buttercup' } \\
\text { Solution-only } \\
\text { R. periclymenoides }\end{array}$ & $\begin{array}{l}8.5 \mathrm{a} \\
2.0 \mathrm{~b} \\
0.1 \mathrm{~b} \\
0.0042\end{array}$ & $\begin{array}{l}\text { 'Buttercup' } \\
\text { Nontreated } \\
\text { Solution-only } \\
\text { R. periclymenoides }\end{array}$ & $\begin{array}{l}17.9 \mathrm{a} \\
4.7 \mathrm{~b} \\
2.5 \mathrm{~b} \\
1.3 \mathrm{~b} \\
0.0002\end{array}$ \\
\hline $\begin{array}{l}\text { Wax } \\
\text { treatment }\end{array}$ & $\begin{array}{l}\text { 'My Mary' } \\
R \text {. canescens } \\
\text { Solution-only } \\
\text { Nontreated }\end{array}$ & $\begin{array}{l}3.2 \mathrm{a} \\
1.0 \mathrm{~b} \\
0.9 \mathrm{~b} \\
0.8 \mathrm{~b}\end{array}$ & $\begin{array}{l}\text { 'My Mary' } \\
\text { R. canescens } \\
\text { Solution-only }\end{array}$ & $\begin{array}{r}R . c c \\
44.6 \mathrm{a} \\
11.8 \mathrm{~b} \\
8.8 \mathrm{~b}\end{array}$ & $\begin{array}{l}\text { nescens leaves (resist } \\
\text { 'My Mary' } \\
\text { Nontreated } \\
R \text {. canescens } \\
\text { Solution-only }\end{array}$ & $\begin{array}{r}50.4 \mathrm{a} \\
14.5 \mathrm{~b} \\
13.2 \mathrm{~b} \\
6.4 \mathrm{~b}\end{array}$ & $\begin{array}{l}\text { 'My Mary' } \\
\text { R. canescens } \\
\text { Solution-only }\end{array}$ & $\begin{array}{l}5.2 \mathrm{a} \\
0.4 \mathrm{~b} \\
0.1 \mathrm{~b}\end{array}$ & $\begin{array}{l}\text { 'My Mary' } \\
\text { R. canescens } \\
\text { Nontreated } \\
\text { Solution-only }\end{array}$ & $\begin{array}{r}12.6 \mathrm{a} \\
1.0 \mathrm{~b} \\
0.3 \mathrm{~b} \\
0.1 \mathrm{~b}\end{array}$ \\
\hline
\end{tabular}

${ }^{\mathrm{z}}$ Surviving adult female lace bugs at $96 \mathrm{~h}$. Each replication included four adult female lace bugs.

yFrass on treated side of leaves at $96 \mathrm{~h}$.

Frass on nontreated side of leaves at $96 \mathrm{~h}$.

wEggs on treated side of leaves at $96 \mathrm{~h}$.

vEggs on nontreated side of leaves at $96 \mathrm{~h}$.

uThe recipient of treatments.

The donor of leaf wax, solution-only treatment, or nontreated.

sAll reported values are means over five replications.

rMean separation based on LSD at $P<0.05$. Means followed by the same letters are statistically similar. 

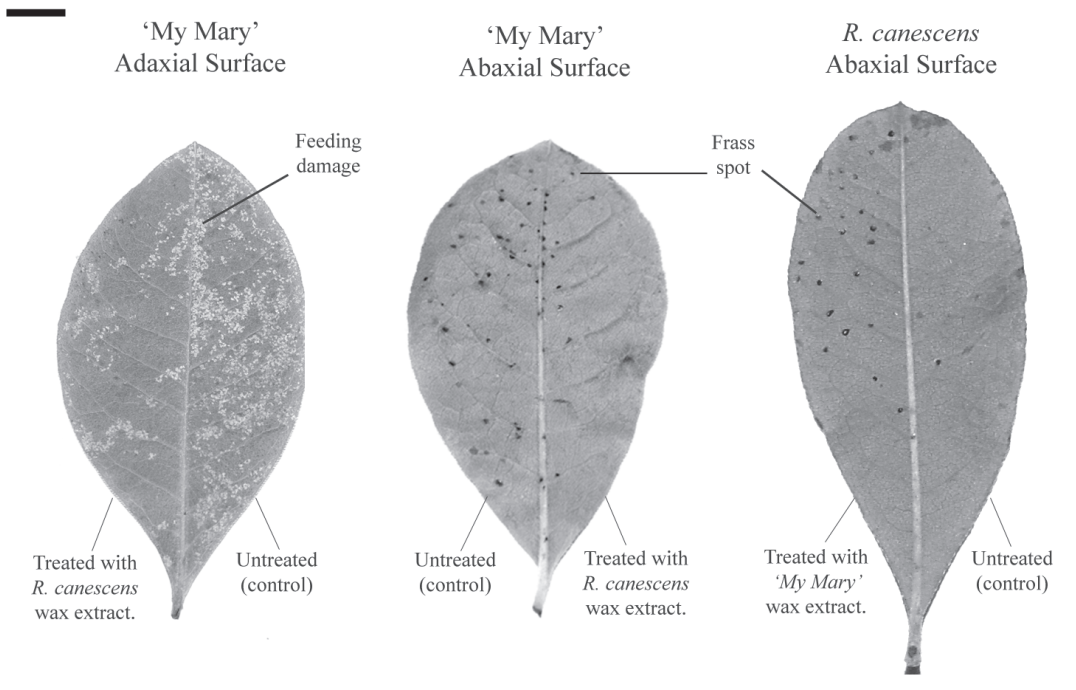

Fig. 1. Deciduous azaleas showing azalea lace bug feeding damage and frass deposition. 'My Mary' (susceptible) adaxial leaf surface treated with Rhododendron canescens (resistant) leaf wax solution on the left side of the midrib (left), 'My Mary' abaxial leaf surface treated with $R$. canescens leaf wax solution on the right side of the midrib (center), and $R$. canescens abaxial leaf surface treated with 'My Mary' wax extract on the left side of the midrib (right). Distance bar (top left) represents $1.0 \mathrm{~cm}$.

wax extract was 2.9, comparable to that of the solution-only mean 19.2. Conversely, treatment of 'My Mary' leaf surfaces with 'My Mary' wax extract showed a significant effect on the level of susceptibility compared to the solution-only control.

Azalea lace bug oviposition. Egg deposition is an indirect measure of feeding, as eggs are typically deposited only on foliage of susceptible genotypes capable of supporting nymphal feeding and development. Oviposition rate on foliage of susceptible genotypes treated with resistant wax extract were significantly reduced compared to susceptible controls, probably due to significantly higher ALB mortality and a reduction in feeding of live ALB in these treatment combinations. Mean number of eggs on 'Buttercup' leaf surfaces treated with $R$. periclymenoides wax extract was reduced from the 'Buttercup' solution-only mean of 14.6 to 0.9 (Table 1). Similarly, mean number of eggs on 'My Mary' leaf surfaces treated with $R$. canescens wax extract was reduced from the 'My Mary' solution-only mean of 13.3 to 1.5. Conversely, oviposition was significantly increased on resistant genotypes treated with susceptible wax extracts. Mean number of eggs on R. periclymenoides leaf surfaces treated with 'Buttercup' wax extract was increased from the $R$. periclymenoides solutiononly mean of 2.0 to 8.5 . Mean number of eggs on $R$. canescens leaf surfaces treated with 'My Mary' wax extract was increased from the solution-only mean of 0.1 to 5.2. Treatment of leaf surfaces with wax from the same genotype neither positively nor negatively affected the resistance or susceptibility of genotypes in this study. Mean number of eggs on R. canescens leaf surfaces treated with $R$. canescens wax extract was 0.4 , comparable to the solution-only mean of 0.1 . Mean number of eggs on 'Buttercup' leaf surfaces treated with 'Buttercup' wax extract was 14.8, comparable to the solution-only mean of 14.6.

EPICUTICULAR LEAF WAX EFFECTS ON UNTREATED LEAF SURFACES. The effects of epicuticular leaf wax extracts, in addition to significantly impacting ALB behavior on treated leaf surfaces, also significantly impacted behavior on nontreated leaf surfaces. Resistant wax extract had a significant impact on susceptible cultivars in both frass deposition and oviposition, again due to significantly higher ALB mortality in treatment combinations including wax solution of resistant genotypes. When $R$. periclymenoides wax extract was applied to 'Buttercup' leaf surfaces, mean number of frass spots on nontreated leaf surfaces was reduced from the 'Buttercup' nontreated and solution-only (control) means of 112.9 and 68.7, respectively, to 6.5 (Table 1). Mean number of eggs on nontreated leaf surfaces was reduced from the 'Buttercup' nontreated and solution-only means of 25.9 and 13.8 , respectively, to 0.3 . When $R$. canescens wax extract was applied to 'My Mary' leaf surfaces, mean number of frass spots on nontreated leaf surfaces was reduced from the 'My Mary' nontreated and solution-only means of 119.3 and 56.6, respectively, to 13.1. Mean number of eggs on nontreated leaf surfaces was reduced from the 'My Mary' nontreated and solution-only means of 29.4 and 12.7 , respectively, to 0.3 .

The same effect was noted when wax extract of susceptible genotypes was applied to resistant genotypes. When 'Buttercup' wax extract was applied to $R$. periclymenoides leaf surfaces, mean number of frass spots on nontreated leaf surfaces was increased from the nontreated and solution-only means of 47.6 and 20.4, respectively, to 82.6. Mean number of eggs on nontreated leaf surfaces was also increased from the $R$. periclymenoides nontreated and solution-only means of 4.7 and 2.5, respectively, to 17.9. Similarly, when 'My Mary' wax extract was applied to $R$. canescens leaf surfaces, mean number of frass spots on nontreated leaf surfaces was increased from the $R$. canescens nontreated and solution-only means of 14.5 and 6.4, respectively, to 50.4. Mean number of eggs on nontreated leaf surfaces was also increased from the nontreated and solution-only means of 0.3 and 0.1 , respectively, to 12.6 .

Treatment of leaf surfaces with wax from the same genotypes mirrored controls, with no significant differences observed in frass or egg means with the exception of 'My Mary' frass means. For example, when $R$. canescens wax extract was applied to $R$. canescens leaf surfaces, mean number of frass spots on nontreated leaf surfaces was 13.2, comparable to both nontreated and solution-only values of 14.5 and 6.4, respectively. Mean number of eggs on nontreated leaf surfaces was 1.0, comparable to the nontreated and solution-only values of 0.3 and 0.1 , respectively. When 'My Mary' wax was applied to 'My Mary' leaf surfaces, mean number of frass spots on nontreated leaf surfaces was 93.3, statistically different from the nontreated mean of 119.3 , yet much greater than the $R$. canescens solution value of 13.1. Mean number of eggs on nontreated leaf surfaces was 18.7, comparable to the solution-only mean of 12.7 .

Pairwise Comparisons. To better elucidate the overall effect of wax extracts from resistant and susceptible genotypes on ALB behavior, on treated versus untreated sides of a leaf, a dependent $t$ test (pairwise comparison) was performed on six data subsets (Table 2). Three data subsets yielded significant differences between both frass and/or egg counts on treated versus nontreated sides of foliage. The first subset, significant for both frass deposition and oviposition rate contained resistant genotypes as donor of leaf wax with susceptible genotypes as recipients of leaf wax. The second subset, significant only for oviposition rate, included all treatment groups containing a resistant genotype as a recipient of leaf wax with resistant genotypes as donors of leaf wax. The third subset, significant only for oviposition rate, included all treatment groups containing a susceptible genotype as a wax 
Table 2. Degrees of freedom, mean difference, standard deviation, $t$ value, and probability of $t$ values for pairwise comparison of frass deposition and oviposition counts on treated versus untreated sides of azalea foliage. Data for the resistant genotypes Rhododendron periclymenoides and $R$. canescens were combined, as were the data for the susceptible genotypes 'Buttercup' and 'My Mary'.

\begin{tabular}{|c|c|c|c|c|c|c|c|c|c|c|}
\hline \multirow[b]{2}{*}{ Donor } & \multirow[b]{2}{*}{ Recipient } & \multirow[b]{2}{*}{$\mathrm{df}$} & \multicolumn{4}{|c|}{ Frass deposition } & \multicolumn{4}{|c|}{ Oviposition } \\
\hline & & & Mean & SD & $t$ & $P>|t|$ & Mean & SD & $t$ & $P>|t|$ \\
\hline Susceptible & Resistant & 4 & 1.45 & 6.02 & 0.76 & $0.4658^{\mathrm{NS}}$ & 0.90 & 0.88 & 3.25 & $0.0100^{* *}$ \\
\hline Resistant & Susceptible & 4 & -20.90 & 21.96 & -3.01 & $0.0143^{* *}$ & -8.40 & 4.39 & -6.05 & $0.0002^{* * *}$ \\
\hline Susceptible & Susceptible & 4 & -15.35 & 32.79 & -1.48 & $0.1729^{\mathrm{NS}}$ & -0.65 & 3.22 & -0.64 & $0.5385^{\mathrm{NS}}$ \\
\hline Resistant & Resistant & 4 & -3.30 & 5.24 & -1.99 & $0.0776^{\mathrm{NS}}$ & -0.90 & 0.84 & -3.38 & $0.0082^{* *}$ \\
\hline Solution (control) & Susceptible & 4 & -1.25 & 11.50 & -0.34 & $0.7392^{\mathrm{NS}}$ & 0.70 & 4.45 & 0.50 & $0.6312^{\mathrm{NS}}$ \\
\hline Solution (control) & Resistant & 4 & 0.60 & 3.46 & 0.55 & $0.5970^{\mathrm{NS}}$ & -0.25 & 0.86 & -0.92 & $0.3809^{\mathrm{NS}}$ \\
\hline
\end{tabular}

donor with only resistant genotypes as recipients as leaf wax extract. No significant differences in frass deposition or oviposition were observed on treated versus nontreated sides of foliage within the following data subsets: 1) susceptible genotypes as a recipient of leaf wax and susceptible genotypes as a donor of leaf wax, 2) solution-only control as a treatment. Overall, results of the pairwise comparisons indicate a significant effect of leaf wax extracts from resistant genotypes on ALB feeding and oviposition, and united with results from mean separation (LSD) analysis, it has been determined to be a significant negative effect. Such a strong response of ALB to resistant wax extracts, as concluded from both LSD and pairwise comparisons, is likely due to an epicuticular wax component that serves as a strong deterrent to ALB.

Potential SOURCES OF EXPERIMENTAL ERROR. A comparison of solution-only and nontreated foliage revealed a small yet measurable negative effect on feeding and oviposition of the solution-only application, primarily on susceptible genotypes (Table 1). This solution-only effect does not overshadow or under-represent the effect of wax extracts, and with the exception of the measurement of frass on nontreated 'My Mary' foliage, is no greater than one standard deviation from the mean of nontreated foliage.

No chloroform (or other trace chemicals listed in the chloroform chemical MSDS as present in the chloroform stock solution) were detected in the three tested leaf wax samples of $R$. periclymenoides, R. canescens, and 'Buttercup' (data not shown). Therefore, it was assumed that the chloroform was evaporated prior to resuspension of wax extracts and data was not confounded due to chloroform contamination.

Examination of foliage of $R$. periclymenoides, $R$. canescens, and 'Buttercup,' using a scanning electron microscope revealed no obstructed stomata in any treatment combination (data not shown). Furthermore, photomicrographs showed no disruption of epicuticular wax on leaf surfaces treated with wax solution (Fig. 2). Apparently, leaf wax solution application provided uniform coverage and minimal disruption of the natural leaf surface texture.

The results of this study demonstrate that leaf-surface lipids from resistant deciduous azalea foliage confers a high level of resistance to ALB feeding and oviposition, as first proposed by Balsdon et al. (1995) and Wang et al. (1999). Conversely, susceptible wax extracts conferred moderate susceptibility when applied to resistant genotypes and hence may contain a stimulant to ALB, although its effect is markedly less than that of resistant wax extract. While there have been few studies in woody ornamental crops to determine the specific mechanism of insect resistance, this study conclusively demonstrates that resistance to ALB in azalea follows a pattern identified in many agronomically important crops (Bodnaryk, 1992; Brennan and Weinbaum, 2001; Molenaar, 1984). This response is most likely due to a wax component that serves as a strong deterrent to ALB.

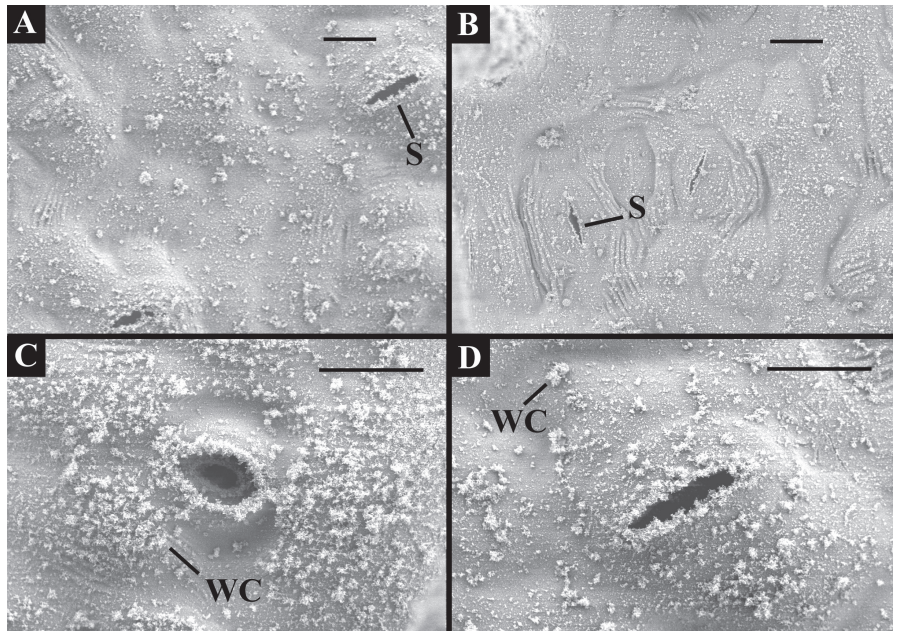

Fig. 2. Scanning electron micrographs of azalea lace bug susceptible cultivar 'Buttercup' foliage treated with wax solution of Rhododendron periclymenoides (panelA and C) and control micrographs of nontreated 'Buttercup' foliage (panel B and D). Stomata (S) and wax crystalloids (WC) are highlighted. Distance bars represent $10 \mu \mathrm{m}$.

Both Balsdon et al. (1995) and Wang et al. (1999) linked several specific chemical components, present in epicuticular wax of ALB-resistant genotypes, to this deterrent effect. Studies are under way to further their work and characterize whether reduced ALB survival, frass deposition (feeding), and oviposition observed on resistant genotypes is due to a specific lipid that serves as a strong deterrent within epicuticular wax and whether increased ALB survival and oviposition in susceptible genotypes is due to a chemical stimulant within epicuticular leaf wax. The future identification of specific epicuticular leaf wax component(s) linked to ALB resistance and susceptibility has the potential to significantly change both ALB resistance breeding and management strategies employed in ALB control.

\section{Literature Cited}

Baker, D., M. Rangappa, and P.S. Benepal. 1985. Comparative leaf morphology of soybean genotypes resistant and susceptible to mexican bean beetle defoliation. Soybean Genet. Nwsl. 15:114-115.

Balsdon, J.A., K.E. Espelie, and S.K. Braman. 1995. Epicuticular lipids from azalea (Rhododendron spp.) and their potential role in host plant acceptance by azalea lace bug, Stephanitis pyrioides (Heteroptera: Tingidae). Biochem. Syst. Ecol. 23:477-485.

Bodnaryk, R.P. 1992. Leaf epicuticular wax, an antixenotic factor in Brassicaceae that affects the rate and pattern of feeding of flea beetles Phyllotreta cruciferae (Goeze). Can. J. Plant Sci. 72:1295-1303.

Braman, S.K. and A.F. Pendley. 1992. Evidence for resistance of deciduous azaleas to azalea lace bug. J. Environ. Hort. 10:40-43.

Brennan, E.B. and S.A. Weinbaum. 2001. Effect of epicuticular wax on 
adhesion of psyllids to glaucous juvenile and glossy adult foliage of Eucalyptis globules Labillardiere. Austral. J. Entomol. 40:270-277.

Buntin, G.D., S.K. Braman, D.A. Gilbertz, and D.V. Phillips. 1996. Chlorosis, photosynthesis, and transpiration of azalea foliage after azalea lace bug (Heteroptera: Tingidae) feeding injury. J. Econ. Entomol. 89: 990-995.

Chapman, R.F., S. Woodhead, and E.A. Bernays. 1983. Survival and dispersal of young larvae of Chilo partellus (Swinhoe) (Lepidoptera: Pyralidae) in two cultivars of sorghum. Bul. Entomol. Res. 73:65-74.

Drake, C.J. and F.A. Ruhoff. 1965. Lacebugs of the world: A catalog (Hemiptera: Tingidae). U.S. Natl. Museum Bul. 213.

Eigenbrode, S.D. and K.E. Espelie. 1995. Effects of plant epicuticular lipids on insect herbivores. Annu. Rev. Entomol. 40:171-194.

Hopkins, W.G. 1995. Introduction to plant physiology. Wiley, New York.

Ishihara, R. and S. Kawai. 1981. Feeding habits of the azalea lace bug, Stephanitis pyrioides Scott (Hemiptera: Tingidae). Jpn. J. Appl. Entomol. Zoology 25:200-202.

Johnson, W.T. and H.H. Lyon. 1991. Insects that feed on trees and shrubs. Cornell Univ. Press, Ithaca, N.Y.

Knust, L. and A.L. Samuels. 2003. Biosynthesis and secretion of plant cuticular wax. Progress Lipid Res. 42:51-80.

Lowe, H.J.B., G.J.P. Murphy, and M.L. Parker. 1985. Non-glaucousness, a probable aphid-resistance character of wheat. Ann. Appl. Biol. 106:555.560.

Mead, F.W. 1967. Stephanitis lace bugs of the United States (Hemiptera: Tingidae). Fla. Dept. Agr. Div. Plant Ind. Entomol. Circ. 62.
Molenaar, N.D. 1984. Genetics, thrips (Thrips tabaci L.) resistance and epicuticular wax characteristics of nonglossy and glossy onions (Allium cepa L.). PhD Diss., Univ. of Wisconsin, Madison.

Neal, J.W., Jr. and L.W. Douglass. 1988. Development, oviposition rate, longevity, and voltinism of Stephanitis pyrioides (Heteroptera: Tingidae), An adventive predator of azalea at three temperatures. Environ. Entomol. 17:827-831.

Nwanze, K.F., R.J. Pring, P.S. Sree, D.R. Butler, Y.V.R. Reddy, and P. Soman. 1992. Resistance in sorghum to the shoot fly, Atherigona soccata: Epicuticular wax and wetness of the central whorl leaf of young seedlings. Ann. Appl. Biol. 120:373-382.

Srinivasachar, D. and R.S. Malik. 1972. An induced aphid-resistant, nonwaxy mutant in turnip, Brassica rapa. Current Sci. 41:820-821.

Tsumuki, H., K. Kanehisa, and K. Kawada. 1989. Leaf surface wax as a possible resistance factor of barley to cereal aphids. Appl. Entomol. Zoology 24:295-301.

Wang, Y., C.D. Robacker, and S.K. Braman. 1998. Identification of resistance to azalea lace bug among deciduous azalea taxa. J. Amer. Soc. Hort. Sci. 123:592-597.

Wang, Y., S.K. Braman, C.D. Robacker, and J.G. Latimer. 1999. Composition and variability of epicuticular lipids of azaleas and their relationship to azalea lace bug resistance. J. Amer. Soc. Hort. Sci. 124:239-244.

Weibel, D.E. and K.J. Starks. 1986. Greenbug nonpreference for blossomless sorghum. Crop Sci. 26:1151-1153.

Weiss, H.B. 1916. Foreign pests recently established in New Jersey. J. Econ. Entomol. 9:212-216. 